\title{
THE SOUTHS OF "THE WEST": GEOCORPOGRAPHICAL ASSEMBLAGES OF PLANTS, COLONIALISM AND RACE IN SERGIO LEONE'S METAFIGURAL SPAGHETTI WESTERNS
}

\section{OS SULS DO "FAROESTE": ASSEMBLAGENS GEO- CORPOGRÁFICAS DE PLANTAS, COLONIALISMO E RAÇA NOS SPAGHETTI WESTERNS METAFIGURAIS DE SERGIO LEONE}

Joseph Pugliese ${ }^{1}$

\begin{abstract}
:
Across many of the travelogues on the Italian South produced by northern European writers, both the prickly pear and the agave emerge as coextensive, in identitarian terms, with the South. Both the prickly pear and the agave are, in fact, plants indigenous to the Americas and they only made their way to the Italian South following the colonisation of the New World. In this essay, I examine the effaced history of colonial economies of occupation, plunder and commercial transport that underpins the existence of these two plants in the Italian South. I then proceed to examine the complex and interlayered systems of signification that, in turn, inscribe these plants in the context of Sergio Leone's Spaghetti Westerns. Leone's Spaghetti Westerns, I contend, must be read as metafigural allegories that bring into focus the complex entanglement of colonialism, race, civil war and contradictory identitarian politics.
\end{abstract}

\section{KEYWORDS:}

Race, Colonialism, Italian South, Spaghetti Westerns, Sergio Leone

\section{RESUMO:}

Ao longo de vários relatos de viagens sobre o Sul italiano, produzidas por autores norte-europeus, a opúncia e a agave emergem como sinônimos identitários do Sul. Porém, tanto a opúncia quanto a agave são, de verdade, plantas oriundas das Américas, que só chegaram no Sul italiano depois da colonização do Novo Mundo. Neste trabalho, examino a história silenciada de economias coloniais de ocupação, pilhagem e transporte comercial que está por trás da presença dessas duas plantas no Sul italiano. Subsequentemente, analiso os complexos e multifacetados sistemas de significação que inscrevem essas plantas no contexto dos Spaghetti Westerns de Sergio Leone. Proponho que os Spaghetti Westerns de Sergio Leone devam ser lidos como alegorias metafigurais que chamam a atenção PARA a complexa interação entre colonialismo, raça, guerra civil e políticas identitárias contraditórias.

\section{PALAVRAS-CHAVE:}

Raça, Colonialismo, Sul da Itália, Spaghetti Westerns, Sergio Leone

1 Doutor em Estudos Anglísticos pela University of Sydney (1992). Diretor de Pesquisa do Departamento de Media, Music, Communication and Cultural Studies da Macquarie University, Sydney, Australia. 
Vegetal Nodes Within an Imperial Network

Reading through the voon the Italian South written by northern Europeans from the eighteenth to the twentieth centuries, I have been repeatedly struck by references to the presence of the prickly pear (Opuntia ficus-indica) and the agave (Agave americana) as signature plants that marked for the travellers the southern identity of the landscape: to catch sight of either of these plants in the landscape was to announce one's entry into the South. In his Italian Journey (1786-1788), Goethe repeatedly remarks on the presence of the prickly pear in the southern landscape. The plant embodies, for Goethe, both the exoticness of the South and its Orientalist impenetrability:

As we neared Misterbianco [Catania], cacti appeared in the hedges, but entire hedges of these bizarre-shaped plants, each more beautiful than the last ...When we tried to beat a downhill path for ourselves through the gardens into the town, we discovered what an impen- etrable barrier a hedge of closely planted cacti can be ... the prickly pear spikes are a painful obstacle ... But we extricated ourselves from this painful labyrinth (GOETHE, 1970, pp. 279-289).

From the eighteenth century onwards, both the agave and the prickly pear become iconic botanical symbols that visually identify the landscapes of the South. In the paintings and prints produced by northern European artists, photographers and travellers, the foregrounded plants literally frame the vistas of the South, precisely as they also graphically signal to the viewer its exuberant and exotic vegetation (Figures 1 and 2). This identitarian coextensiveness of both the prickly pear and the agave with the South has, indeed, been assumed by southern Italians themselves in the marketing and promotion of the South. Both plants have become commodified as marketing symbols that sell touristic fantasies of the South. 


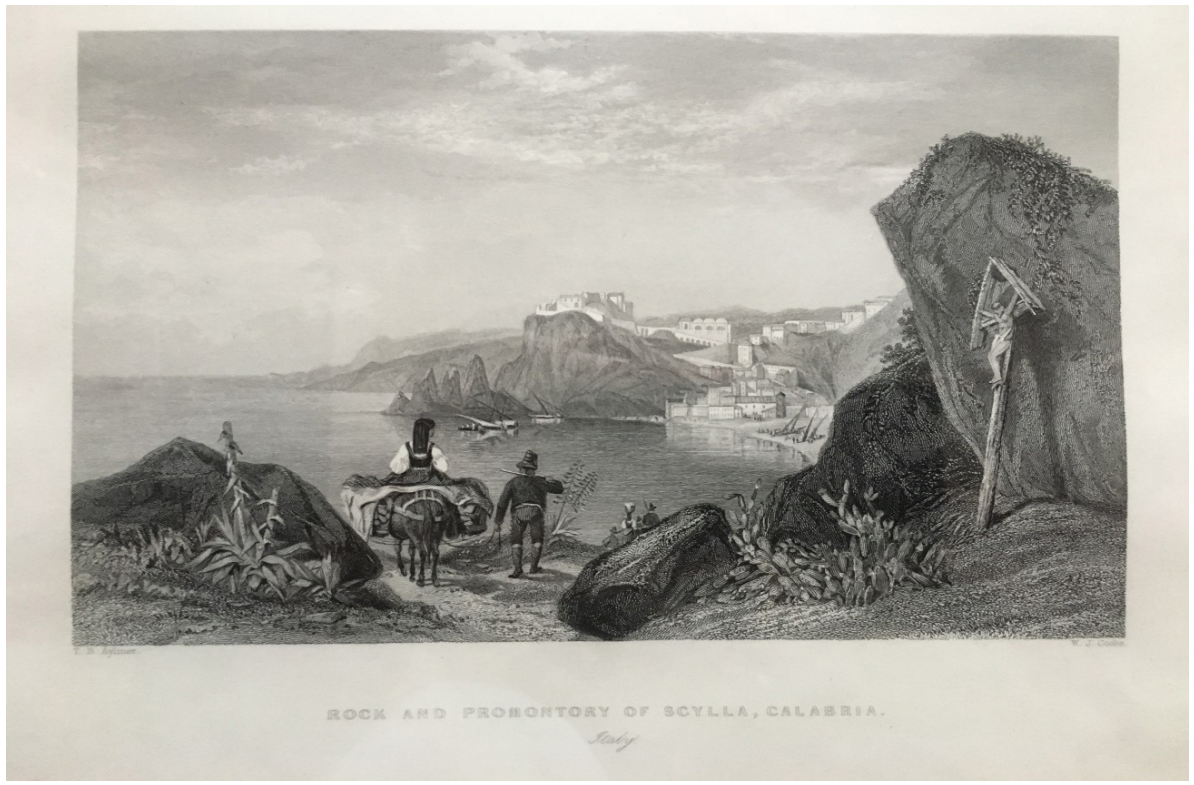

Figure 1. Thomas Brabazon Aylmer, Rock and Promontory of Scylla, Calabria. (Picture credit: Author)

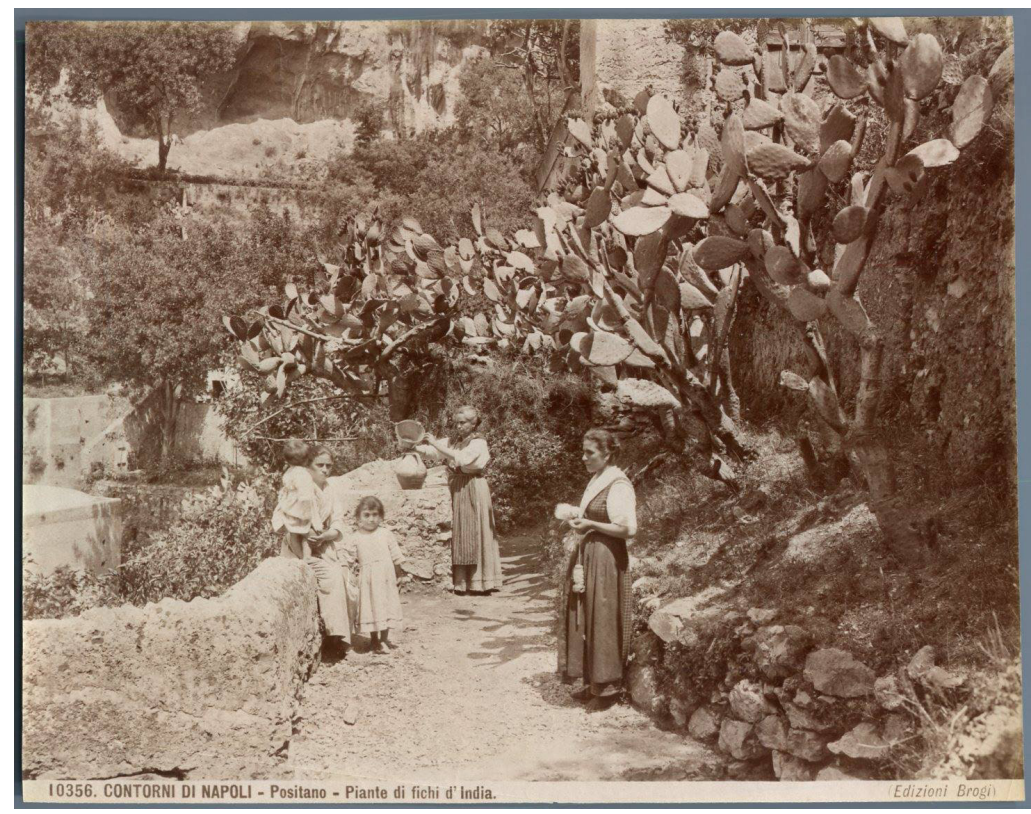

Figure 2. Carlo Brogi, Contorni di Napoli, Positano, Piante di fichi d'India. (Picture credit: Public domain) 
Inscribing representations of the agave and the prickly pear in terms of autochthonous symbols of southern Italian identity is a foundational contradiction. Both the prickly pear and the agave are, in fact, not native to the South; both plants are indigenous to the Americas and they only made their way to the Italian South following the colonisation of the New World. The entry of the prickly pear into Europe has been tracked back to 1493 , the year that Christopher Columbus returned to Lisbon following his landfall on various islands of the New World (CILENTANO. IT, 2017). The agave has been recorded as having been introduced from the Americas into the countries of the Mediterranean in the sixteenth century (DA VARI LETTERATI, 1822, p. 222). The seemingly autochthonous and regional coordinates of southern identity that are embodied by these two plants need, in other words, to be historically situated and geopolitically dispersed. Their entry into the Italian South traces an east- ward journey from the Americas, across the Atlantic and into the Mediterranean countries of Portugal, Spain and thence southern Italy. The Spanish Empire supplies the propellant that enables this eastward trajectory. After a series of wars of Spanish succession, in 1504 Spain assumed control of the Italian South. For over two centuries, the South became one more colony of the Spanish Empire. Characterised by the expansion and consolidation of feudal structures of exploitative oppression, the two centuries of Spanish imperial rule have been termed: "La lunga note del Viceregno" - the "long night of viceregal rule" (PLACANICA, 1999, p. 195-235). ${ }^{2}$ Both the prickly-pear and the agave, in other words, are inscribed by the forces of a double colonialism: the Spanish colonisation of the Americas and the virtually coterminous subsumption of the Italian South under Spanish rule. Both plants work to delineate that geopolitical formation that I have elsewhere termed the "Mediterranean-Atlantic"

2 This and all other translations from the Italian are by the author. 
(PUGLIESE, 2008, p. 8).

Situated within this historical context, both plants emerge as vegetal nodes in a vast network of imperial relations. The anthropocentric dogma of vegetal life as immobile, because rooted to the earth, is here challenged along a number of axes: botanical, political, mercantile, economic and aesthetic. The spatio-temporal transmigration of the prickly-pear and agave eastward across the Atlantic and the lands of the Mediterranean proceeds to configure vegetal life as semiotically fluid and discursively mobile. Reflecting on the complex and mutating relations that bind humans to plants, Michael Pollan notes that: "Witting or not, all these characters have been actors in a coevolutionary drama, a dance of human and plant desire that has left neither the plants nor the people taking part in it unchanged" (2003, p. 261). Identifying the prickly pear and agave as co-actors in larger human dramas is what will enable me to shed light on the semiotic permutations that both plants have undergone in the course of the cultural histories that have shaped them and that they have shaped in turn.

\section{L'America nel Sud: Imperial and Colonial Histories and Spaghetti Westerns}

The 1960s saw the efflorescence in Italy of a genre of the American Western that came to be termed the "Spaghetti Western." In this essay, I will use the term "Spaghetti Western," in contradistinction to the "Italo-Western," for the following political reasons: the genre of the Spaghetti Western is one that was largely developed by southern Italian directors and writers, and it was consciously pitched to southern audiences in the home market of what was termed at the time as the "Roxy, Calabria" (FRAYLING, 2006, p. 63). The "Roxy, Calabria," furthermore, needs to be situated within larger transnational configurations in order to address its expansive diasporic dimensions. The "Roxy, Calabria," as placeholder for the South, extended its reach to key population centres of southern migrants in places such as 
Australia. Post-World War Two, Australia, like the US, Canada and Germany, was a key destination for southern migrants fleeing the chronic poverty of the South. As a boy who grew up in 1960s Sydney, I have vivid memories of watching Spaghetti Westerns at the Australian equivalent of the "Roxy, Calabria": the Grosvenor Theatre, Summer Hill, in Sydney's Inner West. Italian films, including Spaghetti Westerns, were screened on a Saturday night to packed crowds of working class Southerners. The atmosphere in the Grosvenor Theatre was one of excitement, social exchange and entertainment. In keeping with the stratified and interlayered histories of transnational and transcultural relations that have inscribed the South, the "Roxy, Calabria" was, in other words, also a diasporic phenomenon that encompassed southern audiences across the globe.

In proceeding to articulate my reasons for retaining what, on the surface, appears to be a derogatory term, "Spaghetti
Western," I want to map the coextensiveness between the signifiers "spaghetti" and "Southerners"; this coextenisveness can be illuminated by offering a brief politico-semantic history of pasta and the historical coining of "macaroni eaters" as a way of designating Southerners (MONTANARI, 2013, p. 44). From the eighteenth century onwards, Southerners were called "macaroni eaters." The pasta eaters of Naples, for example, became tourist attractions. They would stage spaghetti-eating performances in the streets of Naples for tourists (Figure 3). Tourists would buy plates of spaghetti for the lazzaroni (scoundrels) and street beggars who would, for a fistful of spaghetti, perform the public spectacle of eating the pasta with their hands, dramatically lifting the long strands of spaghetti high up in the air and then consuming them with extravagant flourishes, "much to the amusement of their on-looking benefactors" (BRAUN, 2017). Tourists would photograph this spectacle or buy postcard souvenirs of these 
public performances (Figure 4). torical freighting is exemplified As the photographs of the peri- by the following Risorgimento od make abundantly clear, the anecdote: When Garibaldi, in southern characters in these the course of his military camimages staged choreographic paign of Italian unification, performances of the spaghet- entered Naples on $7^{\text {th }}$ Novemti-eating spectacle. The street ber 1860, he wrote to Cavour: stalls were viewed by the laz- "The macaroni are cooked and zaroni and beggars as stage sets we will eat them" (apud MONwithin which they reflexively TANARI, 2013, p. 43). Through played their respective roles this culinary metaphor, Garibalin a type of street theatre that di signalled that the South was has deep historical roots in the now ready to be consumed by Commedia dell'Arte tradition. its northern conqueror.

The derogatory term "macaroni," moreover, became a racial slur by which to name southern Italian immigrants in countries like Australia and the US. "Spaghetti," thus, is a term that is politically and historically freighted as a synonym for "the South." This politico-his- 


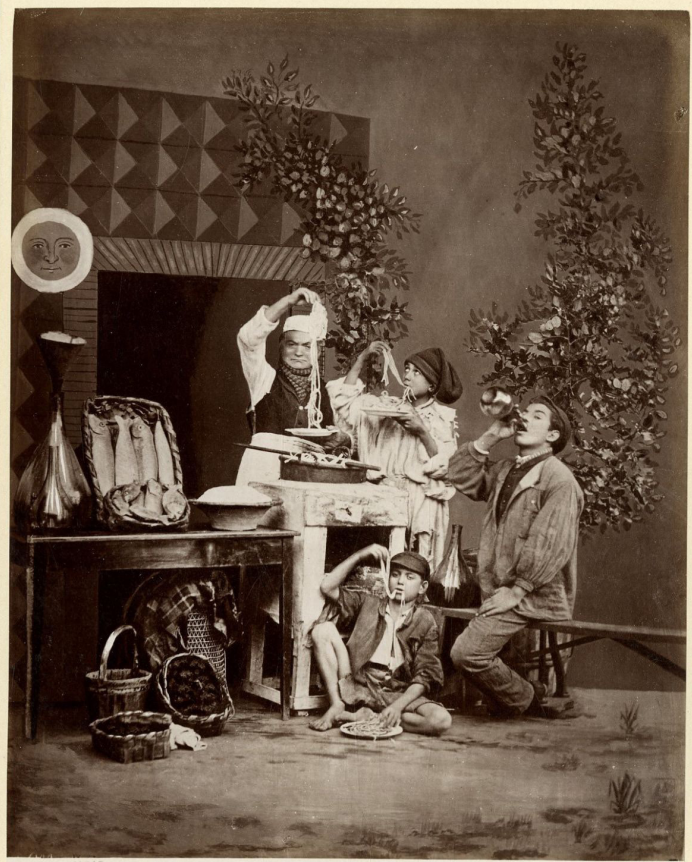

Figure 3. Giorgio Sommer, Spaghetti Eaters, Naples, before 1886. (Picture credit: Public domain)

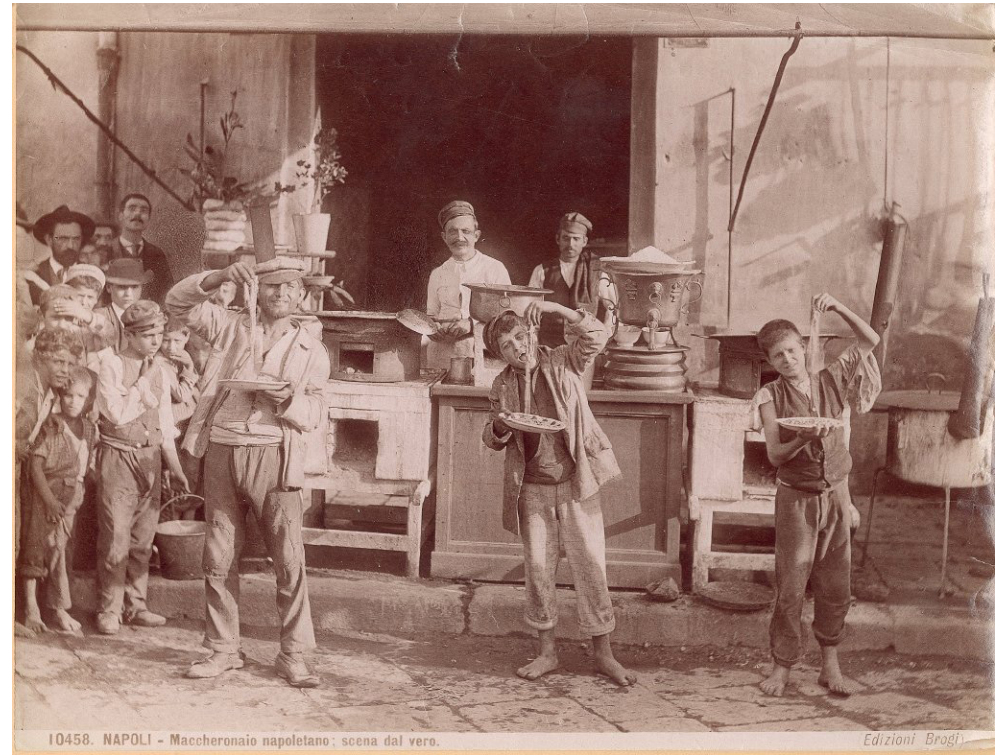

Figure 4. Carlo Brogi, Napoli, Maccheronaio napoletano: scena dal vero. (Picture credit: Public domain) 
By transposing this loaded politico-history of the term to the context of the Spaghetti Western, "spaghetti" emerges as a charged signifier that delineates the epistemological ground of "the South," simultaneously as it resignifies and revalorises the term as a politico-aesthetic category preoccupied with southern issues. $^{3}$ Led by the likes of directors such as Sergio Leone, Sergio Solimma and Sergio Corbucci, the new genre developed its own stylistic attributes, including a selfreflexive play with the traditions of the American Western, scenes of graphic and ritualised violence, choreographic and ceremonial showdowns, the representation of key issues from the Global South, and a realpolitik take on the role of law, outlaws and regimes of (in) justice that generates grey areas that, in Nietzschean terms, shift the moral landscape beyond good and evil. In what follows, my concern will be to situate the Spaghetti Western within the complex locus of imperialism, colonialism and race that I argue continues to supply the discursive infrastructure of the genre. $^{4}$

Due to lack of funds and the exigent practicalities of filming, the bulk of Spaghetti Westerns were shot either in Spain, in the Tabernas Desert of Almeria, or in the Italian South, in places like Sardinia, in the village of San Salvatore di Cabras, and the Abruzzo region. These southern landscapes were seen convincingly to reproduce visions of Mexico, the US Southwest and the border regions interlinking these two territories (BETTS, 1992, p. xi). Agaves and prickly pear plants found in both the southern Italian and Spanish landscapes are key actors in Spaghetti Westerns. They work

3 Leone's humorous ownership of the "Spaghetti Western" moniker is made visually manifest through a visual pun that he stages in the panoramic shot of Flagstone station in one scene at the very beginning of Once Upon a Time in the West where, amongst an array of goods set down on the railway siding, sit two huge barrels stencilled in capital letters “OLIVE OIL” (cf. CUMBOW, 2008, p. 76).

4 For discussions on the representation of gender in Leone's films, see Broughton (2016), Frayling (2012), Cumbow (2008), Landy (1996), Sarris (1968). 
to transmute a Mediterranean landscape into a MexicoAmerican one, imbuing the sites with the necessary aura of "authenticity." A type of double vision inscribes these plants. This double vision functions to problematise the very category of "authenticity" through the operations of the simulacrum. The authenticity of the MexicoAmerican landscape is secured through the nativised simulacra of agave and prickly pear.

These complex processes of transposition and recoding can be amplified by turning our attention to the use of southern Italian actors to play Mexicans in Spaghetti Westerns. In this cinematic schema, Southerners are mobilised as racial analogues in order to pass as their Mexican equivalents. The facility of staging this move was enabled by the perceived isomorphism of phenotypical attributes between southern Italians and Mexicans and the dense racialised histories that so insistently marked the people of the South as outliers within the circumscribed field of European whiteness. Working in tandem with northern racialised imaginaries projected onto the South are the regimes of colonial subjugation that were deployed by the North in order to secure control of the South. The colonial annexation of the South, secured through the violent process of Italian unification, was both predicated and legitimated by the construction of Southerners as racial inferiors of degenerate African and Middle Eastern stock. I have discussed in detail elsewhere the ensemble of racialising practices deployed by Northerners in order to demarcate Southerners as racially other to the white European, and their consequent transmutation into biocriminal types that were congenitally predisposed to violence and criminality (PUGLIESE, 2007; PUGLIESE, 2002).

One can clearly see the instrumentalist rationality of this racio-criminal discourse at work, for example, in one of the reports written by Count Alessandro Bianco di Saint- 
Jorioz, a military man, at the very height of the Guerra Cafona or War on Brigands, 1861-1865. This war, that I will henceforth term as Italy's Civil War (for reasons that I explain below), was fuelled by southern insurgencies that contested the imposition of northern rule on the South and the attendant loss of economic, linguistic, cultural and political autonomy. Italy's Civil War marked a concerted effort by the North to crush and eliminate any opposition to the northern-dominated rule of a so-called "unified" Italy, and thereby to establish the South as a dependent and subjugated colony. In the midst of this civil war, Saint-Jorioz writes:

we are here in the midst of a people that, even though Italian and born in Italy, appears to belong to the primitive tribes of Africa, to the Noueri, the Dinkas, the Malian of Pulo-Penango, and thus it is not appropriate to speak of things that are not even accessible to their intelligence. Here, in other words, there are no communal interests, no trading, no exchanges, no affection, no fraternal love, no mutual admiration, but only hate and jealousy, lust for power and for vendettas; here envy, here all the most base and vile passions, all the most loathsome vices, all the most nefarious iniquities of human nature ${ }^{5}$ (SAINTJORIOZ, 2005, p. 341).

The racially-charged term "Africa" was one repeatedly deployed by northern Europeans in order to describe what they encountered in their travels through the South. The nineteenth-century Swiss writer and traveller, Charles Didier, described inhabitants of the town of Monteleone (Vibo Valentia, Calabria), a town a few kilometres west of my native village, as: "With large black eyes and white teeth, they had the air of small savages ... Surrounded by these semiAfrican peoples, I felt as though I were in a quarter of Timbuctoo

5 "qui siamo fra una popolazione che, sebbene in Italia e nata Italiana, sembra appertenere alle tribù primitive dell'Africa, ai Noueri, ai Dinkas, ai Malesi di PuloPenango, epperciò non è d'uopo parlar qui di cose che non sono nemmeno accessibili alla loro intelligenza. Qui dunque non comuni interessi, non contrattazioni, non scambii, non affetto, non fraterno amore, non mutua stima, ma odio e livore, libidine di potere e vendetta; qui invidia, qui tutte le più base e vili passioni, tutti vizi i più ributtanti, tutte le più nefande nequizie dell' umana natura." 
rather than in an Italian town"6 (DIDIER, 2008, p. 44). The racially-loaded signifier "Africa" performed two mutually constitutive operations: on the one hand, as Europe's master metaphor for everything barbaric, primitive and uncivilised, it worked to secure for northern Italians their stake in the embodied capital of whiteness and the power and privileges that this racial category ensured; on the other hand, through the delineation of a racialised disjunction between Northerners and Southerners, it worked to rationalise the military and paramilitary violence that was unleashed on the South following the foundationally disjointed establishment of national unification. SaintJorioz' racialised description of Southerners emerges from a dense and stratified archive that covers the gamut of epistemic violence: from clinical anthropological analyses to unbridled hate speech.
The continuity of this racial violence is powerfully captured in Francesco Rosi's extraordinary film, Salvatore Giuliano (1962). In Salvatore Giuliano, Rosi, a Neapolitan director, maps the layered complexities, complicities and contradictions that enmeshed the famous bandit, Salvatore Giuliano, in his campaigns of guerrilla warfare in Western Sicily post-World War Two. The power of Rosi's film emerges from the fact that, aside from a few professional actors, he drew on the local townsfolk who had participated in these historical events to re-enact their lived experiences and their performances are both astute and visceral. The early scenes of the film show Giuliano's guerrillas waging a separatist war in order to secure independence for Sicily. The Italian Government responds by sending in the military. In one scene of Rosi's film, as the northern military falls prey to the superior guerrilla tactics

6 "Con I grandi occhi neri e i denti bianchi, avevano l'aria di piccoli selvaggi ... Circondato da questa popolazione semi-africana, mi sembrava di essere in un quartiere di Timbuctù piuttosto che in una città italiana." 
of Giuliano's men, one of the soldiers reflects: "I survived a war, only to get killed by savages in this godforsaken wasteland. Why doesn't Italy just give these people their independence?" As the militarised campaign continues, the government places Montelepre, Giuliano's hometown, under martial law and instigates draconian practices of collective punishment, rounding up all the men of the town, handcuffing them and placing them in chain gangs. Once thus secured, and ready to be dispatched to various prisons, one of the prisoners shouts: "How long will we have to pay for the sin of being born in Montelepre?"As news spreads across the town that the men of Montelepre are to be dispatched to a regime of collective punishment, Rosi stages an intensely affecting scene in which the women of the town pour out of their homes and into the streets; as they run towards their menfolk, they proceed to form a seething human river of impassioned opposition, screaming their outrage at this act of injustice, and then fearlessly breaking like a wave against the armed and mobilised soldiers that form a militarised cordon around the detained men of Montelepre. Salvatore Giuliano's scenes of militarised violence, martial law, the collective punishment of Southerners and the southern campaigns of insurgency and resistance graphically echo Italy's post-unification Civil War.

Sergio Leone's Spaghetti Westerns are unequivocally in dialogue with this violent and racist history. In an interview with a fellow Southerner, Leone declares: "I want to tell you that I'm also a Meridionale, I'm the son of Neapolitan father, I've lived more of my life in Naples than in Rome, even though I was born in Rome"7 (apud DI LELLA, 2009).

The South/North divide that inscribes so many facets of the Italian peninsula and its islands did not fail to mark the field of film studies. The

7 "le dico che sono meridionale anchi'io, sono figlio di padre napoletano, ho visssuto più a Napoli che a Roma, anche essendo nato a Roma." 
directors of Spaghetti Westerns were

looked down upon by the Northern intelligentsia of the film world, not only because of their training in 'pulp' films ... but also because as a result of their training (or their 'occupational ideology,' perhaps) they tended to make 'pulp' films themselves, usually pitched at the home (Southern) market (FRAYLING, 2006, 58).

As such, Christopher Frayling adds, these directors were viewed as not worthy of being included in either serious academic film criticism or histories of Italian film. Writing in 2006, he adds that "Sergio Leone's films do not appear in the standard serious histories of the Italian cinema (or even of the Western) which have been written by Italian film critics" (2006, p. 59). In what follows, I want to examine Leone's films in the context of Italy's South/ North divide and its attendant history of race, colonialism and civil war.

\section{"Il Sangue a Fiumi": Italy's Civil War and Its Rivers of Blood}

Leone takes the violent colonial history that impacted on virtually every aspect of life in the South and cinematically transposes it to the Americas, specifically to the US Southwest, its border regions and Mexico. One of the most powerful scenes in Leone's The Good, the Bad and the Ugly (1966) is of a US southern town laid waste by the forces of the Civil War. Leone has the camera pan over a devastated landscape of incinerated and ransacked houses, of streets cloaked in the smoke of still-smouldering fires. Everywhere that the camera directs its gaze, there is only ruin. For me, this scene vividly evokes what was left in the aftermath of northern troops entering southern Italian towns in the course of Italy's Civil War. Giuseppe Ferrari, a Milanese lawyer, offers an eye-witness account of his entry into the southern town of Pontelandolfo, south of Naples, following the massacre of the civilian population by the Piedmontese troops in 1861:

I had to undertake a journey in order to verify a fact with my own eyes. But I can never begin to express the feelings that stirred in me 
when confronted by that incinerated town....To the right, to the left, the walls had been hollowed out and were blackened, they had set fire to the mounds of furniture on the ground floor and the fire had devoured the roof; from the windows, one saw the sky. Here and there I encountered piles of rubble; it was impossible to go further; the buildings that had been shored up threatened to collapse at any moment $^{8}$ (FERRARI, 2015, p. 168).

This description is what is cinematically reproduced in Leone's The Good, the Bad and the Ugly. As Blondie (Clint Eastwood) and Tuco (Eli Wallach) wend their way through the destroyed southern town, the camera records smoking ruins, mounds of bombed masonry and blasted timber, and homes with no roofs - their ransacked innards exposed to the sky. Roberto Martucci draws on historical records of the period that document the Piedmontese scorched-earth policies that were deployed in the course of Italy's Civil War (2007, p. 305). Once southern towns throughout Calabria, Molise, Abruzzo and Basilicata had been captured by the northern troops, they were invariably plundered and then set alight (SCARPINO 2005, p. 40). In his contemporary account of the war, Giacinto De Sivo writes: "The Piedmontese set fire to not one, not a hundred houses, but to entire towns, shooting with impunity anyone they came across, sparing neither the elderly nor the young"9 (DE SIVO [1861] 2002, pp. 16-17).

One eyewitness describes the massacre that was perpetrated by the northern troops in the town of Casalduni and its subsequent incineration: the violence, he concludes, was as if it were inscribed by an "horizon of

8 "Io ho dovuto intraprendere un viaggio per verificare un fatto cogli occhi mie. Ma non potràmai esprimere i sentimenti che mi agitarono in presenza di quella città incendiata ...A destra, a sinistra, le mura erano vuote e annerite, si era dato fuoco ai mobile ammucchiati nelle stanze terrene e la fiamma aveva divorato il tetto; dalle finestre vedevasi il cielo. Qua elà incontravasi un mucchio di sassi crollati; poi fu vietato progredire; gli edifizi puntellati minacciavano di cadere ad ogni istante."

9 "I piemontese incendiarono non una, non cento case, ma intieri paesi, fucilarono impunemente chiunque venne loro alle mani, non risparmiando vecchi e fanciulli." 
extermination that knew no limits" (apud MARTUCCI 2007, p. 294). A Piedmontese soldier recounts the modus operandi of his battallion on entry into southern towns or villages: "On entering a town, we immediately began to fire on priests and men, whomever we happened upon, with the soldier thence beginning his plunder"10 (apud MARTUCCI, 2007, 288). The Piedmontese soldiers' regime of indiscriminate killing and plunder was further compounded by the deployment of gendered violence that included the sexual assault and rape of southern women (GUERRI, 2011, p. 147, MARTUCCI, 2007, p. 289, DE JACO, 2005, p. 169). The treatment that was inflicted on the captured brigantesse amplified the regime's use of sexual violence in order mark both the vanquishing of the enemy and to advertise, through its trophy photographs, the crushing humiliation that awaited its victims. ${ }^{11}$ The photographs of the captured brigantesse worked to supply the self-evident truths that these women were "beasts or witches" (GUERRI, 2011, p. 170) that violated heteronormative gendered norms because of their masculine dress and conduct. The imprisoned brigantesse appeared, Giordano Bruno Guerri underscores, as "Animals in cages; or, once executed, abused and nude, as trophies of war"12 (2011, p. 170). As Marta Petrusewicz has noted, these photographs clearly referenced those of the same period from across the Atlantic that showed Native Americans as exotic, but-now vanquished, beasts (1998, p. 11).

The brigantessa, Michelina De Cesare, was, after her capture, first tortured and then summarily executed without trial. Her corpse was stripped naked and photographed. Drawing on Suvendrini Perera's

10 "Entrammo nel paese, subito abbiamo incominciato a fucilare preti e uomini, quanti capitava, indi il soldato saccheggiava."

11 For a detailed discussion of the brigantesse in Italy's Civil War, see also GUERRI, 2011, pp. 164-173 and PALOMBO, 2015, pp. 181-271.

12 "Animale in gabbia; o assassinata, seviziata e nuda, trofeo di guerra." 
(2014) acute analysis of trophy photographs in times of war, Marcello Messina and Teresa Di Somma discuss how

Michelina De Cesare's naked, abused and scorned body is a powerful metaphor of Northern Italy's pillaging, exploitation, and domestication of the South ... Femininity is deployed in a specific way here, as it symbolises territories, identities and consciences that need colonial intervention in order to conform to a patriarchal nationalist model (2017, p. 8).

Remarking on how the anthropologist Alfredo Niceforo described Southerners as "un popolo donna" ("a womanly people"), Messina and Di Somma (2017, p. 8) bring into focus how these photographs of racio-gendered violence worked to confirm the hetero-patriarchal position of Northerners in relation to the supine and vanquished feminised body of the South, embodied in the trophy photographs of the brigantesse.

Reproductions of the photos of the slain and naked brigantesse were sent into mass circulation, as were the other images of dead brigands, through the newspapers of Milan and Turin, visually confirming the North's worst prejudices with regard to the barbaric hordes that inhabited the "terre ignote" of the South. The South, after all, was repeatedly framed as Italy's internal Africa. In the words of the Gazzetta di Torino (1861), "[The South] Is a bit like Africa for geographers: we know its boundaries but if we want to push our vision and our thought a bit further, what are we confronted by? Like the geographers in Africa, unknown lands"13 (apud GUERRI, 2011, 79). Reflecting on the photograph of Michelina De Cesare and similar trophy images, Gigi Di Fiore suggests that the image also signified contrary-wise to the intentions of the Piedmontese regime: "The image, however, produced the opposite effect of that which

13 '[Il Sud] È un po' come l'Africa per i geografi: ne conosciamo i confine ma poi se vogliamo spingere un po' più in là l'occhio e il pensiero, che cosa ci troviamo innanzi? Come I geografi nell' Africa, le terre ignote." 
was probably intended by of the period, the Neapolitan whomever commissioned it: historian, Pasquale Villari, it evokes torture, derision, recriminates that, through the sexual abuses"14 (2008, p. legislation passed by the Italian 231). The photographs of the parliament "in order to destroy slain brigantesse and brigands the southern brigandage, we effectivelysomatiseintersecting have let flow rivers of blood"15 relations of power that find (apud MARTUCCI, 2007, p. their literal embodiment in the 312. Emphasis added). Villari's photographic emulsion that phrase powerfully evokes the captures their slain bodies. lexicon of colonial massacre Permanently stilled, as it were, and ethnic cleansing; his by the very photographic fixer charged phrase prefigures used to stabilise the image, they Enoch Powell's infamous remain at once as self-evident peroration on the necessity to and polysemous in their impose draconian and racist significations; as such, they anti-immigrant policies in continue to gesture as revenant Britain in order to prevent the testimonies of violence, subjection and the desire to vanquish unruly bodies in the locus of their own native ground.

The graphic scenes of indiscriminate violence and mass killing that inscribe Leone's films echo the historically documented slaughter of southern civilians by the Piedmontese invading forces. In a revealing letter "rivers of blood" experienced by the United States in its own Civil War. Giuseppe Ferrari, in a sitting of the Italian parliament $\quad\left(20^{\text {th }}\right.$ November 1861), proposed that what was unfolding in the South was, in fact, a civil war. In the transcript of the parliamentary exchange, following Ferrari's denunciation and naming of the atrocities perpetrated by the Northern forces as tantamount

14 "L'immagine ottiene però l'effetto opposto di quello probabilmente voluto da chi la commissionò: evoca torture, dileggi, abusi sessuali."

15 "per distruggere il brigantaggio noi abbiamo fatto scorrere il sangue a fiumi." 
to "una guerra civile" (a civil war), the chamber erupts with cries of denial:

Many voices: No! No! (Noises) Ferrari: [...] But the representatives of the Government have committed grave acts in the southern provinces, acts that place in doubt the very Constitution. There were twelve villages burnt... (Noises of dissent) ${ }^{16}$ (apud MARTUCCI, 2007, p. 323).

Following the commencement of the militarised campaign in the South and the intensification of civil warfare, the Piedmontese regime declared, in the summer of 1862 , martial law over the entire region, including regions that had no insurgent activity. A state of exception was imposed that suspended civil laws and rights and that enabled arbitrary arrests, summary executions, curfews, the prohibition of free movement, the censoring of the press and so on (MARTUCCI, 2007, pp. 323-24). The regime of arbitrary violence, and its attendant system of illegalities, that was imposed upon the
South is powerfully portrayed in Leone's films. He metaphorises this regime through his vision of the West: "I see the history of the West," he notes in one interview, "as really the reign of violence by violence" (apud FRAYLING, 2006, p. 135). In attempting to gloss Leone's uncompromising vision of the West, as portrayed in the Dollars' trilogy, Frayling argues that this violence has its roots in the South's "amoral familism" and its "campanilismo" (2006, p. 191). The "emphasis on all this," Frayling concludes, "firmly locates Leone's rearrangement of the 'codes' of the Western within the context of Southern Italian society" (2006, p. 191). Frayling here trundles out the racist clichés of the northern ethnographer: the reductive categories of "amoral familism" and "campanilismo" reproduce ahistorical stereotypes of southern culture that fail to address the layered racial and colonial histories that continue to inscribe the South. Missing

16 "Molte voci: No! No! (Rumori)Ferrari: [...] Ma i rappresentanti del Governo hanno intrapreso nelle provincie meridionale dei gravissimi atti, i quali mettono in dubbio la Costituzione stessa. Vi furono dodici villaggi incendiati... (Rumori di dissenso)." 
from Frayling's assessment of the South/West interface, and the critical transpositions that Leone stages in his films, is the colonial history of "the reign of violence by violence" that so effectively shaped the South.

In the historical accounts that document Italy's Civil War, colonial analogues are repeatedly called on in order to make intelligible the scale of the violence. Specifically, the colonial wars in both Mexico and the American Southwest are invoked as historical templates. Marzio Proto, a member of the Italian parliament, in a speech delivered on $20^{\text {th }}$ September 1861, argued that the "government of Piedmont wants to treat the southern provinces as Cortes or Pizzaro did in Peru and in Mexico" (apud MARTUCCI, 2007, p. 294) In the Italian lexicon of the period, the American Indies were called the "Indie di lă"and the provinces of the Italian South as the "Indie di quaggiü" -"the Indies over there, and the Indies down here" (apud TETI, 2015, p. 287). Here, the layered histories that bind the Atlantic to the Mediterranean, as emblematised by the agave and prickly pear, are discursively materialised. In his analysis of the homologies between the American West and the Italian South, Austin Fisher coins a phrase that succinctly encapsulates the nexus between the two: "Out West, Down South" (2014, p. 44). Gigi di Fiore, in his account of the Italian frontier wars, writes:

It resembled the wild American West. The events had all the characteristics: pursuits with horses dead with fatigue, assaults on trains and convoys, obligatory military escorts in order to secure the safety of local dignitaries in the course of their travels. ${ }^{17}$ (2005, p. 243)

The tactics deployed by the southern insurgents in the course of the Italian Civil War were, moreover, seen to parallel the guerrilla-style warfare of the Apache Indians (MARTUCCI, 2007, p. 302).

17 "Somigliava al selvaggio West americano. Le vicende ne avevano tutte le caratteristiche: inseguimenti con cavalli morti per la fatica, assalti a treni e convogli, scorte militari obbligatorie per assicurare l'incolumità ai parenti dei notabali locali in viaggio." 
Leone's Cinematic

Terra Nullius and the

'Insignification' of Native Americans

Leone, in his films, stages complex and resonant transpositions of colonial history, war, geography and regimes of racialisation. Situated within these politico-aesthetic movements of transposition, a new intelligibility emerges in terms of the significance of his coding of the landscapes of Spain and the Italian South as coextensive with the landscapes of Mexico and the American Southwest. Palimpsestic histories of colonialism, race and civil war visually resonate in the course of the unfolding of his films. There is, however, a critical lacuna that marks Leone's vision of these colonial landscapes: aside from his Once Upon a Time in the West, which I will presently discuss, there is a gaping ab- sence of Indigenous people in his Westerns. ${ }^{18}$ This critical lacuna cuts across both Leone's US and Mexican films and it effectively works to reproduce a settler-colonial vision in which Indigenous people have been entirely eliminated from their lands in both these contexts. In his writings on both these respective settler states, Jimmie Durham points to the similarities and differences: "While the US advertises itself as a 'nation of immigrants,' Mexico claims that the battle between Cortez and the Aztecs 'was neither a victory nor a defeat, but the birth pains of a new race and a new nation - Mexico'; nullifying the existence of hundreds of 'tribes' who today still fight for enough land to stand on" (1993, p. 179). Durham, moreover, documents the genocidal campaigns waged by the US and Mexico against Yaquis and

18 There appear to be at least two other representations of Indigenous people in Leone's films, but both are questionable on the following grounds: it remains unclear whether the character El Indio (Spanish for "the Indian"), in For a Few Dollars More, is of Indigenous ancestry or whether his name is merely a nickname, as Leone offers no biographical information on his background; in Duck You Sucker, Juan Miranda, as he berates one of the passengers after the stagecoach has been assailed, says in the English dubbed version: "My mother she had the blood of the Aztecs," implying he has Indigenous ancestry. However, in the original Italian version, he says something quite different that signals he has no Indigenous ancestry: "e mia madre, puttana com' era, a te ti avrebbe sputato addosso" ("And my mother, whore that she was, would have spat on you"). 
Apaches (1993, p. 174). The traditional lands of the Yaquis and Apaches cut across and continue to contest the cartographic boundaries of both settler nation-states.

By effacing the presence of Indigenous peoples from the very lands in which he sets his films, Leone re-instantiates the colonial fiction of terra nullius, in which the colonised lands appear devoid of their traditional Indigenous owners. In his Westerns, aside from Once Upon a Time in the West, Native Americans of the Southwest appear neither as noble savages nor as oppressed victims, following the stereotypical dictates of US Westerns; rather, they fail to appear at all. The sweeping panoramic visions of his simulacra of the Southwest landscapes are marked by this haunting absence. In filmic terms, the Indigenous peoples of these lands have been literally relegated to the "space-off," the space that falls outside the scene of representation, that exiles from the space of the screen all that cannot be represented within the settler-colonial cinematic frame. Reflecting on the colonial history of US Westerns, Jimmie Durham writes that "In the last great wave of Hollywood westerns - Shane, High Noon, et al - the hero and the settlers are all by themselves on the endless prairies. They cannot remember when they last had to kill 'Indians."'“'Indians," Durham ironically concludes, have been completely "consumed" (1993, p. 176). The majority of Leone's films continue this genocidal legacy of the erasure of Native Americans from the screen.

In Leone's Westerns, Native Americans' enduring survival of attempted genocide by the forces of settler-colonialism can only be attested to in terms of an invisibilised presence. In this way, Leone's cinematic discourse effectively reproduces the hegemonic position of US settler culture. "Nothing could be more central to American reality," writes Jimmie Durham, than the relationships between Americans and American Indians, yet those relationships are of course the most invisible and the most lied about. The lies are 
not simply a denial; they constitute a new world, the world in which American culture is located. By invasion, murder, theft, complex denial, alibi, and insignification (DURHAM, 1993, p. 138.)

I want to transpose Durham's incisive analysis to Leone's Westerns; specifically, I want to elaborateon the complex and rich semiotics that accrue from his italicising of the prefix "in" in his term "insignification." Through his semanticotypographic manipulation of this term, Durham establishes the possibility for the word to operate in a double register: on the one hand, it signifies "insignificance" (that is, something that possesses no meaning or consequence) and, on the other hand, it evidences the manner in which a term that means "devoid of any significance" is always already inserted in meaningful networks of signification that enable it, paradoxically, to signify the very concept of insignification.

Significantly, the only time Native Americans appear in Leone's The Good, the Bad and the Ugly they are not living subjects but, rather, insignificant cardboard figures lined up as test-targets at the back of a gun shop. Disembodied of flesh and blood, constituted by inanimate material, they emerge as the quintessential exemplar of the subaltern: they cannot speak or engage with the very violent settler-colonial history that is raging around them; rather, they stand as passive victims stamped with the imprimatur of a target on their hearts in order to serve as training fodder for settler gun practice. Tuco aims his gun at the targetpractice Indians, shoots and systematically decapitates all three; with one calculated jump on the rickety floorboards of the shooting gallery, the one figure that remains standing collapses to the ground. With this last intervention, Native Americans are symbolically liquidated from the very locus that they continue physically to occupy and contest in order to secure both their livelihood and unceded sovereignty. In the context of the film, this final gesture of annihilation 
positions Native Americans as having effectively been reduced to a bullseye shooting target, a colonial full stop that signals that they have been inexorably vanquished. The collapse of the final Indigenous figure that had been left standing signals the triumph of Manifest Destiny and its colonial systems of conceptuality, within which Native Americans can only appear as a race doomed to be vanquished by the superior forces of settler colonialism.

In Leone's Westerns, settler campaigns of Indigenous genocide are extradiegetic: they are presented as a priori narratives that establish the conditions of possibility for Native Americans not to appear in his films. As such, when they do appear, as in The Good, the Bad and the Ugly, they can only be represented as ontologically dead shooting targets that evidence the triumphant accomplishment of settler genocide. Leone's settler-genocidal vision of total Indigenous extinction explains the troubling fiction of terra nullius that he reproduces across the majority of his Westerns and why his sweeping landscapes appear devoid of the Native Americans that continue to occupy the very lands from which they have been cinematically effaced.

This terra nullius reading of Leone's Westerns stands to be challenged and complexified when transposed to his epic Once Upon a Time in the West (1968). Native Americans do appear in this film in a number of guises. A Native American character is present in the opening scene in the railway station as Frank's (Henry Fonda) henchmen wait for the arrival of Harmonica (Charles Bronson) in order to kill him. Broom in hand and sweeping the station floor, she is in the employ of the railways. Throughout the scene, as she observes the henchmen's threatening behaviour toward the station master, she remains impassive and silent. As the Native American character senses that a gunfight is about to transpire, she runs off and disappears into the distance, 
a cloud of dust trailing behind her and obscuring her into insignificance. Critically, this opening mise-en-scéne will, as I will presently discuss, bookend the closing shot of the film.

On Jill McBain's (Claudia Cardinale) arrival at Flagstone station, a number of Native Americans characters emerge from the train, tellingly, from the cattle car. As they walk down the plank on to the platform, an overseer says to them: "Get the lead out of your arses you Redskin warriors." All the Native American characters remain silent in the face of this racial slur. It is one of the few times in any of Leone's Westerns that, indirectly, the Indian Wars are referenced. The fact that they are also represented as characters with neither dialogue nor voice and with "lead in their arses" signals that they are socially and politically dead subjects in the landscape of inexorable westward expansion; one of the key burdens of the film is precisely the struggle by settlers to push the railway from the East Coast to the Pacific and the violence and massacres that attended this settler teleology.

In another scene, Frank and his boss, the railroad tycoon Morton (Gabriele Ferzetti), are seen discussing how they can acquire Sweetwater, the estate where Morton wants to build his railway station and that, following their killing of the McBain family, is now in the possession of Jill McBain. This scene is set in a Navajo village situated under the dramatic overhang of an escarpment with sweeping views of the desert. As Frank and Morton discuss their plans and as Frank physically assaults Morton, who is disabled, by knocking away his crutches, the Native American characters in the scene constitute mere backdrop props to the central action unfolding before them; they are there only to supply folkloric colour to the serious matter being discussed by the white men. Once again, not one of the Native American characters is given a voice or agency in this scene in which we have 
the incongruous presence of two strangers who have left the train at the bottom of the valley and have climbed up to an Indigenous village in order to conduct their conversation on how best to secure new land critical to the railway's westward expansion. That the land that these two white men want to acquire is Navajo land is rendered superfluous in the narrative. "There are thousands of pictures of us," says Elsie Mae Cly Begay, a Navajo Elder, "but we never got to say anything" (apud LEWIS, 2010, p. 173). In this scene, the Indigenous subjects are represented as already a vanquished race that can play no role in the unstoppable colonisation of Native American lands.

I come, finally, to an ambiguous crux in Once Upon a Time in the West: the fact that the lead character, Harmonica, is apparently of Native American and Mexican descent. In an interview, Leone states that Harmonica is "A half-breed who implacably pursues revenge. A man who knows just how long to wait, before he kills the man responsible for the death of his brother. Since he is an Indian, he already hates the white man" (apud FRAYLING, 2012, p. 274). The reason that Harmonica pursues Frank throughout the course of the film is because Frank killed Harmonica's older brother by stringing him up by a noose from an arch while his legs rested on Harmonica's shoulders. Whilst in this position, Frank placed the eponymous instrument in Harmonica's mouth. The elder brother, in order to spare his sibling any more trauma, purposefully kicks his younger brother to the ground and thereby hangs himself. Leone adds: "He doesn't talk much. He expresses his sadness with the harmonica. His music is a lament which comes from deep down. It is visceral - attached to an ancestral memory" (apud FRAYLING, 2012, p. 274). The reference to "ancestral memory" appears to signal that Leone was marking the massacres of Native Americans that ensued from settler colonisation of Indigenous lands. 
The troubling ambiguity that inscribes the character of Harmonica in Once Upon a Time in the West is generated by an interplay of key factors. Even as the lead character of Harmonica is presented by Leone as Indigenous, he is not played by a Native American, and this is in keeping with the dominant Hollywood practice of the period. The character, moreover, appears in the film as largely deracinated and devoid of any relational connection to any Indigenous community. Is this because his community been massacred and he is the last survivor? Frayling seems to suggest as much when he says that Harmonica is "the last descendent of 'an ancient race'" (2012, p. 274), even though there is no evidence in the film to suggest as much and, in contradistinction to Leone's other films, Native Americans visibly appear in key scenes of the film. The freighted line "ancient race" comes, in fact, from the exchange between Harmonica and Frank just before their duel. In the exchange, Harmonica remarks:
"An ancient race. Other Mortons will be along, and they kill it off." Here Leone lapses back into the mythos of the Native American as the "dying race," as the "vanishing race" that simply cannot survive the teleological trajectory of settler expansion, as emblematised by the coming railway, across Indigenous lands. Thus, even as Once Upon a Time in the West finally marks in an unequivocal manner the living presence and agency of Native Americans, as represented by Harmonica, it simultaneously announces their inexorable demise and disappearance.

The closing scene of the film, with its elegiac theme, clinches the film's Manifest Destiny thesis. After Harmonica has shot dead Frank Morton, he is seen riding off into the distance on his horse, with the corpse of his friend, Cheyenne (Jason Robards), slung over a horse that is trailing behind Harmonica's. The train steams into the station at Sweetwater that is under construction and that is abuzz with the work of 
the railway gangs. As the film comes to a close, Harmonica, with the dead Cheyenne slung over his trailing horse, is seen disappearing into the distance, leaving behind all the material signs of settler expansion wagons, tools, lumber and so on - that are set to project settlers into the very West towards which Harmonica rides. As the credits begin to role, Harmonica becomes a mere vanishing point in the hazy distance: he, and by definition, his people, have been reduced to "insignificance" in the wake of triumphant settler colonialism. This message, however, is unintentionally undercut by the final line of the film's credits: "The producers are grateful to the Navajo Tribal Council for their hospitality in their territories in Arizona and Utah." In this closing moment, Leone's eulogy on the vanished Native American comes undone. With this final credit, the Navajo literally have the last word on the myth of the vanishing Indian by embodying, in writing, their ontological presence in their homelands of Arizona and Utah and their undiminished, because unceded, sovereignty over their lands. Despite the film's diegetic erasure of Indigenous sovereignty, the Navajo's extradiegetic exercise of "hospitality in their territories" at once attests to and instantiates a living politics of Indigenous sovereignty.

The Asymmetries and Convergences of Parallel Civil Wars

In the Introduction to their edited collection, The American South and the Italian Mezzogiorno, Enrico Dal Lago and Rick Halpern map the parallels that marked both the US and Italian Civil Wars:

The most important historical process which occurred in both countries was the formation of the nationstate. Both the USA and Italy emerged as unified nations in the course of the $1860 \mathrm{~s}$ as a result of ideological and military conquests waged by the two norths against the two souths. It is no accident that the most recent historiography in the USA links the American Civil War to the contemporary national unifications in Europe ... On the other hand, the most recent Italian historiography has been moving in the direction of re-evaluating the 
importance of the experience of military confrontation and the memory of defeat in the North-South divide during the process of Italian Unification. In particular, the expression 'civil war' is increasingly used by Italian historians in order to describe the military operations in which the Piedmontese army fought against the brigands in southern Italy between 1861 and 1865 (DAL LAGO and HALPERN, 2002, p. 18).

Dal Lago and Halpern remark in passing on the differences between the American and Italian Souths. In order to avoid the epistemic violence of historical flattening, these critical differences need to be elaborated. Africans were violently captured by slave traders, forcefully removed from their homelands and placed in lethal modes of transport across the Atlantic, with the resulting death of at least 2 million captives; Africans were sold at auction and thence placed under slave regimes of systemic subjugation and exploitation. Southern Italians were never forcefully removed from the homelands; rather, because of catastrophic economic conditions following Italian unification, they were compelled to migrate in their millions in a type of biopolitical ethnic cleansing. Following unification, the Piedmontese regime sacked the treasury of the Kingdom of the Two Sicilies, stole critical infrastructure and imposed economic tariffs that favoured the northern economy at the expense of the South's (cf. MARTUCCI, 2007, pp. 230332). Those that remained in the South continued to be subjugated to an exploitative regime of "severe subordination ... in spite of their formal legal freedom as late as the beginning of the twentieth century" (BEVILACQUA, 2002, p. 66). Critically, the foundational difference that separates the American and Italian Civil Wars is that the American Civil War was, regardless of the problematic economic and political agendas that inscribed the North's military campaigns, about the abolition of slavery. This is a non-negotiable difference that opens a disjunctive fault line between the two wars. 
Leone's historical erudition is evidenced by the fact that, in contradistinction to Dal Lago and Halpern's above-mentioned claim that the move to understand the military confrontation between the Italian North and South in terms of a civil war is a recent development, he well understood that the historical actors who were contemporaneous with the Italian war described and named it precisely as a civil war. Enea Pasolini, a lancer in the Piedmontese army writing in the 1860s, describes what is unfolding as "una vera guerra civile," a "true civil war" (PASOLINI, 2005, p. 56). Gigi di Fiore documents how the term "civil war" entered the vocabulary of the period precisely in order accurately to describe the militarised Piedmontese campaigns that were being conducted in the South (MARTUCCI, 2007, p. 219). Dal Lago, in his "Radicalism and Nationalism, 1830-60," in the same volume, delineates the fundamental difference between the regime of slavery that subjugated African Americans and the system of latifon- di or large landed estates that tied southern Italian landless peasants to the "landowners by particularly usurious contracts" (DAL LAGO 2002, p. 200). He then proceeds to articulate the parallel legacies left in the wake of the conclusion of the respective civil wars, focusing on the self-construction of both Norths as "liberators" of "the southern masses," who were represented in the northern discourses "as helpless victims longing for help coming from the outside" (DAL LAGO 2002, p. 210). This binary construction effectively worked, Dal Lago argues, to create "a history of dependency of the two souths upon the norths for social change and it contributed to northern discrimination against ex-slaves in the American South and against peasants in the Italian South" (DAL LAGO, 2002, p. 210).

Dal Lago, however, then proceeds to make the extraordinary claim that "the actual shape that the discrimination took was different, because of the non-existence of a racial factor in Italy" (DAL LAGO, 2002, p. 
210). This is an untenable claim that flies in the face of the historical evidence, and it is very much in keeping with the ongoing elision by Italian historians of the crucial role that race played in the process of Italian Unification and its subsequent Civil War. Vito Teti is one of the few historians to document and analyse the constitutive role of race in the construction of Italian identity. His landmark text, La Razza Maladetta (The Damned Race), meticulously documents the insistent and often rabid racialisation of Southerners by the North throughout the course of the nineteenth and into the twentieth centuries by such figures as Alfredo Niceforo, Cesare Lombroso, Giuseppe Sergi and so on. The work of these scholars, as Teti demonstrates, established a racist canon that effectively influenced northern politicians, doctors, psychiatrists, magistrates, anthropologists, journalists and the larger domain of northern popular culture. As Marta Petrusewicz notes, the "language of the parliamentary debates on brigandage was imbued with racialised terms, and the language of pathology, of degeneration, of inferiority"19 (1998, p. 11). As a self-declared Meridionale, Leone was fully cognisant of this entrenched racialised history and he effectively embedded it representationally in his films. As I discuss in the closing section of this essay, many of the directors, scriptwriters and, crucially, the actors were also reflexive of this racial history.

In The Good, The Bad and the Ugly, Tuco embodies the Southerner. In a rare move for Leone, unlike any of the other main characters in the film who remain largely blank in terms of their biographies, he has Tuco speak of his history of poverty and disenfranchisement. In an exchange between Tuco and Father Pablo Ramirez, Tuco says philosophically, "where we come from, if one did not want to die of poverty, one became a priest or a bandit." In this pithy biography, Tuco encapsulates

19 "il linguaggio dei dibattiti parlamentari sul brigantaggio era impregnato di termini razziali, di malattia, di digenerazione, di inferiorità." 
the options available to the Southerner post-unified Italy. In the film, Betterville, the prisoner of war concentration camp, emerges as a metaphor for the concentration camps to which southern prisoners of war were dispatched following their capture by northern forces. The then-Minister of War, Manfredo Fanti, estimated that there were about " 30,000 or 40,000 prisoners of war" that were now under the aegis of the Piedmontese military (apud MARTUCCI, 2007, 215). The Piedmontese regime constructed a vast carceral archipelago that extended across the peninsula and that was defined by punitive regimes of torture and the deprivation of the most elementary needs (ANGNOLI, 2005, 12). The southern prisoners of war were effectively framed by classist and racist categories that worked to legitimate the imposition of these punitive carceral regimes (MARTUCCI, 2007, p. 203). General La Marmora, charged with inspecting these concentration camps and confronted by the squalor and misery in which the prisoners were held, made no moves to disguise his profound contempt for the southern prisoners of war: he described them as little more than "dregs" and a "herd of carrion" (apud MARTUCCI, 2007, p. 215).

The most infamous of these camps was Fenestrelle (cf. IZZO, 1998, pp. 73-89). Francesco Proto Carafa, a politician of the period, denounced the conditions of these camps in the Italian parliament:

They [the prisoners of war] are treated worse than convicts. What crime have they committed, compelling the Piedmontese Government to explain why it has indulged in such cruelty? Why has it tortured with starvation and immobilisation and prison men born in Italy like us? ${ }^{20}$ (apud IZZO, 2005, p. 89).

Leone's powerful evocation of the Piedmontese prisoner of war camps in The Good, The Bad and The Ugly works to stage a resonant crossover between the Italian and the American Civil Wars. An Italian newspaper

20 "Sono essi trattati peggio che i galeotti. Qual delitto hanno commesso eglino, perchè il governo piemontese abbia a spiegar tanto lusso di crudeltà? Perchè abbia a torturare 
of the period (1861), in an impassioned denunciation of the appalling conditions within which southern prisoners were held, clearly referenced the African American brethren across the Atlantic and the then-unfolding US Civil War when it declared that Italy's southern prisoners were being treated as bad as Black slaves ("peggio che non si fa coi negri schiavi") (apud MARTUCCI, 2007, p. 219).

The contempt felt by the Piedmontese government toward the southern prisoners of war is best illustrated by the fact that it considered the option of ethnically cleansing the newly-formed nation of its unreconstructible human detritus by deporting the prisoners of war either to the Portuguese colonies in India or the British colony of Australia (SCARPINO, 2005, p. 155). Here the lines of colonialism, empire and race intersect and proceed to amplify themselves across transnational and geopolitical axes. As Salvatore
Scarpino sardonically remarks, "The children of the brigands themselves took care to 'selfdeport,' by emigrating"21 (2005, p. 156). Through the process of the Southerners' "selfdeportation," I would add, the North's racialised chickens came home to roost, as millions of terroni were compelled to migrate to northern cities in order to escape the grinding poverty and unemployment of the South, a region virtually untouched by Italy's postwar "economic miracle." Lee Broughton locates the emergence of Spaghetti Westerns at this historical juncture:

Around three million Southern Italians had been forced to migrate North in search of work during the 1950s and the rude reception that these dark-skinned Southerners received in Northern cities - and the poverty-stricken conditions that they had to endure resulted in the longstanding economic, cultural and racial tensions that had traditionally existed between the North and the South of Italy becoming the subject 
of growing public discourse.

The Italian Western was born out of this historical moment (BROUGHTON, 2016, p. 84).

It was in this period that Southerners living in the North's cities would be racially categorised by Northerners as "'africano' [African] and 'marocchino' [Moroccan]" (BROUGHTON, 2016, p. 84), even as Southerners effectively worked under exploitative and squalid conditions, doing the jobs that Northerners saw as beneath them. Broughton underscores how Spaghetti Westerns increasingly assumed the dimensions of political allegories that addressed the tensions and crises of the period. The Southernisation of the Western not only encompassed political, racial and economic concerns, it also extended to the very aesthetics of the genre, including the use of "traditional Sicilian folk instruments" (BONDANELLA, 1983, p. 256) and elements of the Pupari or Sicilian puppet theatre (FRAYLING, 2006, p. 131).

The torture of Tuco by
Angel Eye's henchmen, whilst held captive in the prisoner of war camp, is performed to Ennio Morricone's haunting ballad "The story of a soldier." The music, as a sign of civilisational culture, is what accompanies the physical violation and trauma of Tuco, as embodiment of the South. Leone thereby opens a violent disjunction between the North's claims to civilisational culture and its deployment in the South of campaigns of torture and massacre that included decapitating their southern victims and displaying their heads on stakes in town squares and crossroads as symbols of deterrence. "Politics," says Leone, "are never absent from my films" (apud FRAYLING, 2012, p. 306); neither, I would add, is history. The graphic display of executed and mutilated bodies that inscribes Leone's civic landscapes references this historical practice. The mutilated corpses of Southerners were, in the manner of the lynching photographs of the American South, photographed 
by a squadron of mobile photographers employed by the Piedmontese military. They were expected to be on call and to make rapid entries into the militarised zones of operation in order to photograph both southern captives and corpses. These photographers massproduced cartes de vistes of their southern subjects, both dead and alive, that were sent into circulation as symbolic trophies and macabre souvenirs that self-evidenced the subhuman status of their quarry. These photographs were a huge commercial success and they contributed to the spread, amongst the good northern bourgeoisie, of a visual imaginary that confirmed their prejudices of Southerners as the worst of the worst (DI FIORE, 2008, p. 230). Drawing on the work of Perera (2014), Messina and Di Somma articulate the manner in which these trophy photographs worked to establish disjunctive and asymmetrical regimes of spectatorship and violence: "the public is ... divided between a dominant component whose members are supposed to watch the violence as entertainment and social leisure, and a subaltern, racialised component, whose members are terrorised by the violence" (MESSINA \& DI SOMMA, 2017, p. 4).

The photographs of tortured and executed Southerners were also incorporated into the racialised studies of criminal anthropologists, such as Cesare Lombroso, supplying further positivistic evidence of the biocriminal status of Southerners. Their corpses were dismembered and their skulls were sent to be "examined, measured, sectioned and studied with attention by military medics, followers of Lombroso's theories" (DI FIORE, 2008, p. 228). Having examined the skull of an executed Southerner, the brigand Vilella, Lombroso writes:

Looking at that cranium, I seemed to have a moment of illumination on the question of the nature of the criminal; he is an active being that reproduces in his person the ferocious instincts of primitive humanity and of the 
inferior animals ... the love of orgies, the irrepressible hunger for evil in itself, the desire to not only extinguish the life of his victims, but also to mutilate the corpse, to rip apart the flesh and to drink its blood. ${ }^{22}$ (apud DI FIORE, 2008, p. 228)

Lombroso's hantasmagorical picture of the depraved and bestial Southerner is satirically realised in Leone's Duck, You Sucker, also known by the more accurately political title of Once Upon a Time ... The Revolution (1971). In the opening scene of the film, the first thing Leone's camera focuses on when it turns to reveal the character of Juan Miranda (Rod Steiger), a Mexican bandit, are his dust-covered feet. The camera then proceeds to hover over Juan's feet, as he slowly scrapes them through the dirt. Leone here establishes a visual pun that will be amplified in the coming scenes. Juan's dirt-covered feet stand as the visual metonym for northern Italians' racial slurring of Southerners as terroni, that is, as the very dirt beneath one's feet because they are uncivilised and savage cafoni. Emerging from the desert landscape, Juan manages to flag down a luxurious stagecoach carrying a number of haute bourgeois passengers. The coach driver agrees to give him a lift as a way of performing a joke by placing a filthy and savage cat amongst the refined pigeons.

On his entry into the luxuriously appointed coach, the first thing all the passengers do is focus on Juan's grime-covered feet: to their horror, a terrone has literally entered their inner-sanctum. In a mocking gesture aimed at accommodating their civil protocols, Juan immediately removes a pair of sandals from his jacket's pocket and proceeds to wear them before he moves any further. Juan's entry causes expressions of disgust and consternation. He is then spoken to by one of the passengers as if he were a child. One passenger duly di-

22 "Vedendo quel cranio, mi sembrò di avere un'illuminazione sul problema della natura del criminale; un essere attivo che reproduce nella sua persona gli istinti feroci dell'unmanità primitiva e degli animali inferiori ... l'amore per le orge, la brama irresistibile per il male in sé, il desiderio di spengnere non solo la vita della vittima ma anche di mutilare il cadavere, di squarciare la sua carne e di bere il suo sangue." 
rects him to pull out a small seat from the wall at the back of the cabin and paternalistically says to Juan: "Now just sit down and be quiet like a good little boy." Thus begins a chorus of classist and racist abuse from a selection of characters that represent the pillars of upper-class society, including a landowner, a cardinal, a US businessman from the Deep South and so on. As each passenger begins to voice their abuse of Juan and what he embodies, Leone stages a choreography of close-ups that juxtaposes a series of masticating, grimacing and contorted mouths that, in turn, effectively reduces the characters to a grotesque chorus of voracious orifices, thereby underscoring their parasitical status in relation to the all the classes beneath them from which they draw their wealth and status. One passenger spits out that the likes of the world's Juans are "Animals, that's what they are, animals." The priest chimes in with: "Personally, I consider them unfortunate brutes." The white businessman from the Deep South remarks that back in the US, "we call them 'niggers,'” and then philosophically reflects that "Every country has got its own plague. Just like them niggers we got back home." The woman passenger exclaims that "They are all promiscuous. All sleeping in the same room ... like rats in a sewer." "Just like animals, because that's what they are," remarks another. Leone here evidences the operations of the biopolitical caesura that effectively divides the human from the nonhuman animal, thereby positioning the nonhuman animal subject as object and as a lower form of biological life (cf. PUGLIESE, 2013, pp. 32-46).

All the racist and classist slurs voiced against Juan exactly echo those that northern Italians have deployed against the terroni. Nowhere is this perhaps best encapsulated than in the rant by Count Alessandro Bianco di Saint-Jorioz, who was writing in the context of the Italian Civil War. In his writings (1860-1863), he offers this candid overview of Southerners:

The almost complete absence of a moral sense, the lacking 
of any elementary knowledge of the dictates of honour, of probity, of modesty; the disorderliness of dress; the immorality in everything and everyone; the robbery, the embezzling, the strikes and the bad faith in the articles of law; everything, in sum, that is obscene and should be rejected by human society is found diffused and reproduced in grand copies amidst this miserable people. ... His [the Southerner's] senses are dumb, his mind is uncultivated, unknown are the dictates of good and evil, he is an animal, a brute ${ }^{23}$ (SAINT-JORIOZ, 2005, pp. 340-343).

Leone, in the stage coach scene, works in a double register: On the one hand, he establishes a network of relations that extends back to the violence of the Italian Civil War and that large archive of racist, anti-southern texts that effectively established the instrumentalist-rationalist template that would legitimate the need for the colonial annexation of the South and the enormity of the violence that had to be deployed in order to secure this civilising mission. On the other hand, he stages in this same scene a caustic commentary on the very contemporary scene of raceclass conflict that was unfolding in the North's metropolises with its large migrant populations of terroni.

\section{"Questo è il Messico": The Class-Race Nexus of the Borgate's Spaghetti Western Actors}

The race-class nexus that Leone has Mexican characters like Juan or Tuco embody in his films was, indeed, a felt political experience for many of the southern and Roman workingclass actors that were employed to play Mexicans in Spaghetti Westerns. In a largely-forgotten documentary, L'America a Roma (1998), the politics of these actors comes clearly through during the interviews with the director, Gianfranco Pannone. These little-known actors lived in the outer suburbs of Rome,

23 "la mancanza di senso morale pressoché totale, la nessuna elementare conoscenza dei dettami d'onore, di probita, di pudore; la sregolatezza nei costume; l'immoralità in tutto e in tutti ... la rapina, il malversare, lo sciopero e la malafede fatti articoli di legge; tutto insomma ciò che vi è di lado ed di riprovere nella umana Società si trova in gran copia diffuso e penetrato in queste misere popolazioni.... I suoi sensi sono muti, la sua 
in the borgate, marginalised spaces populated by terroni, sub-proletariat, sex workers and queers. One of the terms used by the dominant culture to describe these marginalised spaces exposes the complex imbrication of race, colonialism and exclusion from the civic culture of hegemonic Italianness: "'villaggi abissini" ('Abyssinian villages')" (apud FORGACS, 2014, p. 32). Here Italy's colonial outposts in North Africa, specifically, Abyssinia, are symbolically imported back into its metropolises precisely in order to demarcate the internal borders of racialised otherness. Yet another term deployed to name the marginalised borgate was

"coree" ("Koreas"), a term that emerged shortly after the Korean War of 19501953 and that apparently was derived from the fact that the established residents of the surrounding areas saw the migrants, most of whom were from poor areas of southern or northeast Italy or from Yugoslavia, as "like exiles, refugees, like people who had lost a war" (FORGACS, 2014, p. 32).
For the terroni, this was in fact the case: they had lost the battle in the Italian Civil War and were reduced to exiles who had to flee their own lands due to the infrastructural poverty and disenfranchisement that had been imposed by the North on the South; they were refugees in the very country to whom they apparently owed allegiance and that had, in name only, officially designated them as "Italian citizens." The non-white nomenclatural terms, "Abyssinian villages" and "Koreas," deployed to describe the borgate, work to construct racialised geographies that are internal to the nation, even as they symbolically demarcate and excise these same spaces from the corpus of the Italian nation. Simultaneously, these non-white terms evidence the racialising operations through which northern Italians sought to secure and consolidate their purchase on whiteness and, tautologically, on their Europeanness. As I discuss below, the residents of the borgate were reflexive of these

mente incolta, ignoti i dettami del bene e del male, è un animale, un bruto." 
racialising operations and, in clear gestures of solidarity, they defiantly embraced and celebrated their collective affiliation with those racially designated as outcasts.

As he films in the borgata of Mandrione, situated on Rome's outskirts and that once had a film studio that rivalled Cinecittà, Pannone narrates: "Mandrione is the other face of the economic miracle. Dropouts from the economic miracle lived here. Migrants from the South and Rome's underclass ... people who struggled to make ends meet" (PANNONE, 1998).

One of the interviewed Spaghetti Western actors, Guglielmo Spoletini, says: "The world of the Mexicans has been transferred amidst our borgate. The borgate are populated with real Mexicans because these people continue to struggle across all of Rome's borgate. Mexico is all around us and Rome sits in the middle" (apud PANNONE, 1998).

As he walks through the streets of the borgata, Spoletini declares: "This is Mexico!" (apud PANNONE, 1998). In this instant, Spoletini names the geocorpographical relation that inextricably ties a cluster of subalternised people under one sign, "Mexico" - a sign that binds cinematic fictions with the embodied and lived realities of struggle, institutionalised disenfranchisement, classism, racism and colonialism across different geopolitical spaces. ${ }^{24}$

In the course of the interview, Spoletini says: "I felt more Mexican than American, because the Mexicans were always mistreated, they were a people that was always harassed by the Americans (...) it is a political question. I only played an American a few times, because my sympathy lay with this people who were poor and who were subjected to so many harassments" (PANNONE 1998). Spoletini further elaborates his political vision in the context of the roles he played in Spaghetti Westerns: "The Mexicans are like Indians: they always lose. They've always fought to win

24 For a discussion of the term "geocorpography," see Pugliese (2007). 
their freedom. The Indians are still suffering. Whenever I played a Mexican, I felt I was really fighting for something" (PANNONE, 1998). The impassioned manner in which political affect was embodied in these actors' performances is powerfully evidenced by the words of Tomas Milian, the Cuban actor who was a staple in so many Spaghetti Westerns:

The fact that I was a Latino made me love my characters even more, because I always had inside my head: 'You son of a bitch' ... Towers (a white character in The Big Gundown) the bounty killer, Towers the Anglo, and how he racistically greets me in a certain way, so that fed my anger (GREGORY 2005).

Carlo Lizzani, the director of Requiescant (1967), set in the time of the Mexican Revolution, draws attention to how many directors were compelled to cast their political stories in allegorical mode because a regime of "censorship was imposed by the market. If instead of making Requiescant, which was a metaphor for revolutionary aspirations, we'd made a film on an uprising by southern Italian peasants, we'd have been stopped" (apud PANNONE 1998).

Requiescant is a wonderfully subversive film on many levels, not the least in Lizzani's choice to have the director Pier Paolo Pasolini - openly and, for the period, notoriously gay play a pious priest who simultaneously advocates liberation theology and revolution. Pasolini, in true drag fashion, crosses the costumes of peasant, priest and revolutionary in order to queer the heteronormative macho characters of traditional Westerns. Rome's borgate would, of course, give birth to so many of Pasolini's characters and they would provide the locations for a number of his films.

\section{Leone's Metafigural Allegories}

I commenced this essay by tracing a brief historical itinerary of the agave and prickly pear in the context of Italian South. Tracking the imperial, colonial, racial and geopolitical histories that have inscribed these plants, I then proceeded to 
establish points of connection between the different Souths that are bound in topological relations that extend from the Americas across to the lands of the Mediterranean. As I remarked in the opening pages of this essay, these relations establish the geopolitical formation that I have termed the "Mediterranean-Atlantic" (PUGLIESE, 2008, p. 8). My entry into these histories of parallelism, intersection, rupture and differentiation was literally enabled by my reflection on the existence of the agave and prickly pear in the land of my birth, Calabria, and their inscriptive status as nativised imports. As nativised imports, these two plants mark a domain of signification that references, always already, the multiple Souths of the West and their intersecting, differential and colliding histories. These plants have enabled me to excavate and trace the complex historical layers and intertwined politico-historical relations that I have discussed in the course of this essay. As actors in the various dramas of the West's multiple Souths, they emerge as vegetal nodes of distributed cognition that embody histories that, for me, would otherwise have remained invisibilised and unspeakable. As epistemological agents, they delineate a complex discursive network that establishes lines of relations that encompass multiple levels of imperial power and colonial violence, including Spanish, AngloAmerican and PiedmonteseItalian. Discursively, they effect a topological enfolding of various Indies (both American and southern Italian), parallel civil wars (US and Italian) and subaltern subjects (Native Americans, terroni, Mexicans), even as they mark, through their dis/placements and celluloid virtualities, the fault lines of rupture and incommensurable difference that inscribe the subjects of these geocorpographical assemblages.

In questioning my reevaluation and valorisation of these two plants, one might argue that the agave and prickly 
pear are mere bit players in Spaghetti Westerns and that, as such, they can be dismissively relegated to the marginalised domain of accessories that are eccentric to the field. Yet, it is the very fact that these two plants occupy, in deconstructive terms, "a corner whose eccentricity assures the solid concentration of the system, participating in the construction of what it at the same time threatens to deconstruct" (DERRIDA, 1989, p. 73). As I demonstrate below, as mere bit players whose roles are confined to the literal edges of a mise-en-scéne - for example, the agaves that literally populate the corners of the final shoot-out in For $a$ Few Dollars More - the agaves assure the construction of the representational system of a Mexican border village (Agua Caliente) that, at the same time, through their very Spanish location (Los Albaricoques, Almeria), they deconstruct.

The agave and prickly pears that populate Spaghetti Westerns must be seen as at once denotative and connotative in terms of their signifying status. On the one hand, they stand as vegetal literalities that self-represent the signifiers "agave" and "prickly pear" and the doubly resonant signified: "plants of the Americas' Souths." In the wake of 1492 and the imperial and colonial histories that this historical moment unleashed, the polyvocality that these plants now speak cannot be categorically isolated and divided. This polyvocality is what establishes the conditions of possibility for the emergence of the allegorical mode. As actors in the landscapes of a South that is at once of the Americas and in the Mediterranean, they set the stage for the possibility of the ruse of 'authentic' visions of the US Southwest and Mexico to be realised - simultaneously as they work to allegorise, for example, the racial and colonial history of the Italian South. The extraordinary power of Leone's films resides, I contend, in his ability to magnetise the tensions, similarities and differences that result from this topological formation of polyvocality, intersection, 
difference and aporia. His films compel the viewer to ask: Which South of the West is being represented? Which Southerner is speaking? Which history of the South is being addressed? The impossibility of supplying either/or answers to these questions underscores the deconstructive power of the allegorical mode when it is operating at the metafigural level. The palimpsestic and metafigural dimensions that inscribe Leone's work, and that make it impossible to isolate and demarcate categorical borders, is perhaps best illustrated by the manner in which The Good, the Bad and the Ugly is at once about the American Civil War, the Italian Civil War and, by geocorpographical definition, the Spanish Civil War - the film was shot largely in Spain, with the anti-Franco, pro-Republican town of Almeria serving as one of the key filming locations.

\section{Leone's films have} been celebrated for their metacinematic qualities and their rich layers of intertextual citations. His films, however, also need to be seen as metafigural, and this is perhaps most memorably emblematised in the opening scene of Once Upon a Time in the West. Leone, at one point, positions Frank's henchmen inside the railway station in a setting that unequivocally evokes and plays with Velázquez' famous painting Las Meninas (1656). Leone made a close study of Las Meninas during his repeated visits to the Prado Museum when he was filming in Spain. He viewed the painting, in his words, "as much about the process of image-making as it was about its ostensible subject matter." He underscores how he saw the "painting as parable" that influenced him in terms of its representation of outsiders, including "the beggars, the infirm, the dwarfs," and its extraordinary metavisual qualities (apud FRAYLING, 2012 p. 233). As in Velázquez' Baroque painting, the figures in the railway station are situated in a complex interplay of perspective, interlayered frames, foreground and depth, light and darkness, illumination 
and obscurity, mirrors and reflections, and multiple gazes. Encapsulated in this scene of the film are Leone's signature visual tropes and, simultaneously, the metafigural forces that inscribe his work.

Leone's Westerns are metafigural precisely because they establish, in Paul De Man's terms, allegories "of a figure (for example, metaphor) which relapses into the figure it deconstructs" (1979, p. 275). In contradistinction to the canonical US Westerns, where the West is presumed to be selfidentical to itself (the West "is" the West), ${ }^{25}$ in Leone's films the West emerges as an allegorical figure that can be neither selfidentical nor autotelic as it is bound by an inextricable system of topological, differential and aporetic relations; as such, it relapses into the figure it deconstructs: in other words, the West, in Leone's films, is always already its Other/Wests/ Souths. Here a deconstructive topology sets in disarray the seemingly fixed points of the compass and it enables the emergence of geographical coordinates that conjoin the West to its many Souths and that superimpose spatiotemporal configurations that defy categorical delimitations. Leone's tropic transpositions and metafigural re-citations destabilise univocal meanings. It is precisely because Leone's West is, in his filmic hands, ineluctably other to itself that the West's many Souths come into filmic being.

\section{References}

AGNOLI, F. M. Prefazione. In IZZIO, F. I lager dei Savoia: Storia infame del Risorgimento nei campi di concentramento per meridionali. Napoli: Controcorrente, 2005, p. 7-23.

BETTS, T. Foreword. In WEISSER, T., Spaghetti Westerns: The Good, the Bad and the Violent: A Comprehensive, Illustrated Filmography of 558 Eurowesterns and Their Personnel, 1961-1977. Jefferson, North Carolina and

25 This shifts in the late 1960s, following in the wake of the rise of the Native American Red Power movement and the US massacres perpetrated in the Vietnam War, with the West also assuming, in a number of US films, the allegorical mode in order to comment on these significant socio-political events (cf. ROLLINS \& O'CONNOR, 2003). 
London: McFarland \& Company, Inc., Publishers, 1992, pp. xi-xiii. BEVILACQUA, P. Peter Kochin's 'American South' and the Italian Mezzogiorno: Some Questions about Comparative History. In DAL LAGO, E. and HALPERN, R., The American South and the Italian Mezzogiorno: Essays in Comparative History. Basingstoke and New York: Palgrave, 2002, pp. 60-72.

BONDANELLA, P. Italian Cinema: From Neorealism to the Present. London: Continuum, 1983.

BRAUN, A. Eating Spaghetti by the Fistful Was Once a Neapolitan Street Spectacle. Atlas Obscura, 8 May, 2017. http://www. atlasobscura.com/articles / spaghetti-eaten-by-hand-naples. BROUGHTON, L. Euro-Western: Re-framing Gender, Race and the 'Other' in Film. London and New York. I. B. Tauris, 2016.

CILENTANO.IT. Opuntia ficusindica: il fico d'india. Cilentano. IT: Notizie e manifestazioni dal Cilento e dall'Italia. 2017. http://ilcilento.altervista.org/ blog/opuntia-ficus-indica-il-ficodindia/

CUMBOW, R. C. The Films of Sergio Leone. Lanham, Marylands: Scarecrow Press, Inc, 2008.

DA VARI LETTERATI. Biblioteca italiana o sia giornale di letteratura, scienze ed arti. Milano: Imperiale Regia Stamperia, 1822.

DAL LAGO, E. and HALPERN, R. Two Case Studies in Comparative History: The American South and the Italian Mezzogiorno. In DAL LAGO, E. and HALPERN, R., The American South and the Italian Mezzogiorno: Essays in Comparative History. Basingstoke and New York: Palgrave, 2002, pp. 3-25.

DAL LAGO, E. Two Great Migrations: American and Italian Southerners in Comparative Perspective. In DAL LAGO, E. and HALPERN, R., The American South and the Italian Mezzogiorno: Essays in Comparative History. Basingstoke and New York: Palgrave, 2002, pp. 197-214.

DE MAN, P. Allegories of Reading: Figural Language in Rousseau, Nietzsche, Rilke and Proust. New Haven and London: Yale University Press, 1979.

DE SIVO, G. L'Italia e il suo dramma politico nel 1861. Napoli: Editoriale Il Giglio, 2002. DERRIDA, J. Memoires for Paul de Man. New York: Columbia University Press, 1989.

DI FIORE, G. Controstoria dell'unità d'Italia: Fatti e misfatti 
del Risorgimento. Milan: Rizzoli, 2008.

DIDIER, C. Viaggio in Calabria. Soveria Mannelli: Rubbettino, 2008.

DURHAM, J. A Certain Lack of Coherence: Writings on Art and Cultural Politics. London: Kala Press, 1993.

FERRARI, G. Un deputato in Pontelandolfo distrutta. In DE JACO, A., Il Brigantaggio Meridionale: Cronaca inedita dell'Unità d'Italia. Roma: Editori Riuniti, 2005, pp. 168-70.

FISHER, A. Radical Frontiers in the Spaghetti Western: Politics, Violence and Popular Italian Cinema. London and New York: I. B. Tauris, 2014.

FORGACS, D. Italy's Margins: Social Exclusion and Nation Formation since 1861. Cambridge: Cambridge University Press, 2014. FRAYLING, C. Sergio Leone: Something to Do with Death. Minneapolis: University of Minnesota Press, 2012.

FRAYLING, C. Spaghetti Westerns: Cowboys and Europeans from Karl May to Sergio Leone. London: I. B. Tauris, 2006.

GOETHE, J. W. Italian Journeys, 1786-1788. London: Penguin, 1970 [1816].

GUERRI, G. B. Il sangue del sud:
Antistoria del Risorgimento e del brigantaggio. Milano: Oscar Mondadori, 2011.

IZZO, F. I Lager dei Savoia: Storia infame del Risorgimento nei campi diconcentramento per meridionali. Napoli: Controcorrente, 2005. LANDY, M. Cinematic Uses of the Past. Minneapolis and London: University of Minnesota Press, 1996.

LEWIS, R. Navajo Talking Picture: Cinema on Native Ground. Lincoln and London: University of Nebraska Press, 2012.

MARTUCCI, R. L'Invenzione dell'Italia Unita: 1855-1864. Milan: Sansoni, 2007.

MESSINA, M. and DI SOMMA, T. Unified Italy, Southern Women and Sexual Violence: Situating the Sexual Assault TV 'Prank" Against Emma Marrone Within the Dynamics of Contemporary Italy as a Scopic Regime, Tropos, Comunicação, Sociedade e Cultura, vol. 6, no. 1, 2017, pp. 1-18.

MONTANARI, M. Italian Identity in the Kitchen, or Food and the Nation. New York: Columbia University Press, 2013. PALOMBO, L. The Racial Camp and the Production of the Political Citizen, PhD Thesis, Macquarie University, 2015, pp. 
181-271.

PASOLINI, E. Immondezzaio fisico e morale. In DE JACO, A., Il Brigantaggio Meridionale: Cronaca inedita dell'Unità d'Italia. Roma: Editori Riuniti, 2005, pp. 56.

PERERA, S. Dead Exposures: Trophy Bodies and Violent Visibilities of the Nonhuman, Borderlands, vol. 13, no. 1, 2014, pp. 1-26.

PETRUSEWICZ, M. Come il Meridionale divenne una Questione: Rappresentazioni del Sud prima e dopo il Quarantotto. Soveria Mannelli: Rubbettino Editore, 1998.

PLACANICA, A. Storia della

Calabria: Dall'antichità ai giorni nostri. Roma: Donzelli editore, 1999.

POLLAN, M. The Botany of Desire: A Plant's-Eye View of the World. London: Bloomsbury, 2003.

PUGLIESE, J. State Violence and Execution of Law: Torture, Black Sites, Drones. Abingdon and New York: Routledge, 2013.

PUGLIESE, J. Whiteness and the Blackening of Italy: La guerra cafona, extracommunitari and Provisional Street Justice, Portal, vol. 5, no. 2, 2008, pp. 1-35.

PUGLIESE, J. Geocorpographies of Torture.Australian Critical
Race and Whiteness Studies Association Journal, vol. 3, no. 1, 2007, http://www.acrawsa.org. $\mathrm{au} /$.

PUGLIESE, J. White Historicide and the Returns of the Souths of the South. Australian Humanities Review, vol. 42, 2007, http:// www.lib.latrobe.edu.au/AHR/ archive/Issue-August-2007/ Pugliese.html.

PUGLIESE, J. In the Ruins of Diaspora. In SIEGEL, K., Issues in Travel Writing: Empire, Spectacle, and Displacement. New York: Peter Lang, 2002, pp. 229244.

ROLLINS, P. C. and O'CONNOR, J. E. Hollywood's Indian: The Portrayal of the Native American in Film.Lexington: University Press of Kentucky, 2003.

SAINT-JORIOZ, A. B. Un militare si guarda intorno. In DE JACO, A.,

Il Brigantaggio Meridionale: Cronaca inedita dell'Unità d'Italia. Roma: Editori Riuniti, 2005, pp. 340-43.

SARRIS, A. Spaghetti and Sagebrush. Village Voice, vol. 19, no. 26, September 1968.

SCARPINO, S. La guerra 'cafona': Il brigantaggio meridionale contro lo Stato unitario. Milano: Boroli Editore, 2005.

TETI, V. La Razza Maledetta: 
Origini del pregiudizio LEONE, S., dir.The Good, the Bad antimeridionale. Roma: Manifesto and the Ugly, 1966.

Libri, 1993.

TETI, V. Terra Inquieta: Per un'antropologia dell'erranza LEONE, S., dir.Duck, You Sucker, meridionale. Soveria Mannelli: 1971.

Rubbettino, 2015.

Filmography

LIZZANI, C., dir. Requiescant, 1967.

GREGORY, D., dir. The Spaghetti PANNONE, G., dir. L'America a West, 2005.

LEONE, S., dir.A Fistful of Dollars, 1964. Roma, 1998.

LEONE, S., dir.For a Few Dollars Data de recebimento: 05/12/2017 More, 1965 